\title{
Keciciran Murid Sekolah di Malaysia: Suatu Pemerhatian Awal
}

\section{(School Dropouts in Malaysia: A Preliminary Observation)}

\author{
Norfarahzatul Asikin Zakari(iD, Mohamad Zuber Abd. Majid², Muhammad Hussin³ \\ 1Fakulti Pendidikan, Universiti Kebangsaan Malaysia (UKM), 43600, Bangi, Selangor, Malaysia. \\ Email: p112820@siswa.ukm.edu.my \\ ${ }^{2}$ Fakulti Pendidikan, Universiti Kebangsaan Malaysia (UKM), 43600, Bangi, Selangor, Malaysia. \\ Email:mzuber@ukm.edu.my \\ ${ }^{3}$ Fakulti Pendidikan, Universiti Kebangsaan Malaysia (UKM), 43600, Bangi, Selangor, Malaysia. \\ Email: muhsin@ukm.edu.my
}

\section{CORRESPONDING \\ AUTHOR (*):}

Norfarahzatul Asikin Zakari

(p112820@siswa.ukm.edu.my)

\section{KATA KUNCI:}

Keciciran

Pendidikan

Faktor

Langkah pencegahan

\section{KEYWORDS:}

Dropout

Education

Factors

Preventions

\section{CITATION:}

Norfarahzatul Asikin Zakari, Mohamad Zuber Abd. Majid \& Muhammad Hussin. (2022). Keciciran Murid Sekolah di Malaysia: Suatu Pemerhatian Awal. Malaysian Journal of Social Sciences and Humanities (MJSSH), 7(2), e001288. https://doi.org/10.47405/mjssh.v7i2.1288

\begin{abstract}
ABSTRAK
Hasrat kerajaan untuk merapatkan jurang pendidikan dalam kalangan rakyat Malaysia adalah melalui Kementerian Pendidikan Malaysia dengan menyediakan pendidikan kepada semua warganegara tanpa mengira latar belakang. Namun begitu, masalah dalam pendidikan khususnya keciciran pelajar kerap berlaku dan semakin membimbangkan di semua peringkat pengajian. Sehubungan dengan itu, kertas konsep ini bertujuan memperincikan beberapa faktor yang telah dikenal pasti sebagai penyumbang berlakunya keciciran dalam pendidikan. Faktor disebabkan oleh sosioekonomi keluarga, personaliti pelajar dan faktor luaran seperti budaya dan persekitaran, pengaruh rakan sebaya serta cara pengajaran guru telah dikenal pasti sebagai antara punca keciciran pelajar. Oleh itu, langkah- langkah mengatasi berlakunya keciciran turut diperincikan berdasarkan kajian lepas. Justeru, pelbagai langkah telah diambil oleh semua pihak terutamanya guru, sekolah, kementerian mahupun kerajaan dalam membendung penularan masalah ini. Antaranya adalah tingkatkan kesedaran ibu bapa, motivasi dan minat pelajar serta mempelbagaikan gaya pengajaran untuk menarik minat pelajar supaya tidak tercicir.
\end{abstract}

\section{ABSTRACT}

The government's intention to bridge the education gap among Malaysians is through the Ministry of Education Malaysia by providing education to all citizens regardless of background. However, problems in education, especially student dropouts, are frequent and increasingly worrying at all levels of education. Hence, this concept paper aims to address several factors that have been identified as contributors to the occurrence of dropouts in education. Factors such family socioeconomics, student personality and external factors such as culture and environment, peer influence and the way teachers teach have been identified as among the causes of student dropout. Therefore, 
preventions to overcome the occurrence of dropouts are also discuss based on previous studies. Various measures have been taken by all parties, especially teachers, schools, ministries, and the government in curbing the spread of this problem such as to increase parental awareness, motivation and interest of students and diversify teaching styles to attract students to decrease the dropout.

Sumbangan/Keaslian: Kajian yang dijalankan ini diharapkan dapat memberi sumbangan kepada pelajar, guru-guru, sekolah dan juga kementerian untuk memahami secara mendalam akan faktor-faktor dan langkah -langkah mengatasi keciciran dalam pendidikan.

\section{Pengenalan}

Kerajaan Malaysia telah menekankan akses kepada pendidikan untuk semua dan telah mencadangkan pelbagai garis panduan dan matlamat pendidikan untuk merapatkan jurang pendidikan, pengeluaran dan kemahiran merentasi semua sektor sejak penubuhan Malaysia. Tindakan kerajaan adalah untuk memastikan semua kanak-kanak, tanpa mengira jantina, etnik, latar belakang sosio-ekonomi, atau lokasi, mendapat akses dan menamatkan pendidikan rendah. Sejak 2012, kerajaan telah menerima pakai dasar pendidikan percuma, dengan menyasarkan kepada beberapa kumpulan secara amnya dikategorikan kepada tiga kategori pendapatan iaitu Below 40 (B40), Middle 40 (M40) dan Top 20 (T20) (Subra et al., 2019). Golongan sasaran yang dituju adalah daripada golongan B40 iaitu golongan pendapatan keluarga di bawah gaji bulanan minimum. Ini termasuk kanak-kanak daripada keluarga atau penempatan miskin bandar, luar bandar dan pinggir bandar, kanak-kanak yang tinggal di kawasan terpencil, kanak-kanak berkeperluan pendidikan khas, kanak-kanak orang asli dan tidak berdokumen, kanakkanak yang tinggal di ladang dan pelarian. Di samping itu, dalam Perkara 12 Perlembagaan Malaysia menyatakan bahawa setiap warganegara tidak boleh didiskriminasikan dalam menerima pendidikan formal. Perkara ini disebut dalam Perkara 8 Perlembagaan Malaysia, yang memperuntukkan hak sama rata dalam pendidikan formal bagi setiap warganegara tanpa mengira agama, bangsa, asal usul atau jantina (Perlembagaan Malaysia, 2013). Pada 2015, kerajaan telah membentangkan laporan kajian semula pendidikan untuk semua rakyat Malaysia di Forum Pendidikan Dunia di Incheon, Korea Selatan. Kerajaan telah berusaha sedaya upaya untuk menyediakan pendidikan percuma dan berkualiti dalam semua bidang dengan memperkenalkan pelbagai inisiatif.

Pendidikan yang berkualiti adalah penting kerana sektor pendidikan turut menyumbang kepada pertumbuhan ekonomi sesebuah negara. Pendidikan adalah pendorong di balik pertumbuhan sumber daya manusia yang berpengetahuan dan berkemahiran tinggi. Sistem pendidikan mestilah memenuhi keperluan industri dan ekonomi serta mampu menjana modal insan yang inovatif, produktif dan berkemahiran. Hal ini kerana modal insan keluaran dari produk pendidikan akan menjadi guna tenaga serta ejen kepada pertumbuhan dan pembangunan ekonomi negara. Pertumbuhan ekonomi kini didorong oleh industri berasaskan pendidikan dimana keperluan guna tenaga yang kualiti tinggi dan pertumbuhan guna tenaga yang mampan adalah asas penting untuk mengubah ekonomi daripada negara berpendapatan sederhana kepada negara berpendapatan tinggi (Norkhatijah et al., 2012). Oleh karena itu, pada era ekonomi yang dipandu oleh kemajuan sains, Malaysia sangat membutuhkan keterlibatan individu yang 
berpengetahuan untuk memastikan pembangunan dan pertumbuhan ekonomi yang seimbang dalam jangka masa Panjang.

Hal yang demikian, kerajaan Malaysia menerusi Kementerian melalui Kementerian Pendidikan Malaysia (KPM) sangat berkomitmen untuk melaksanakan transformasi sistem pendidikan nasional selama 15 tahun ke depan. Transformasi pendidikan ini bertujuan untuk membekali setiap siswa di negara ini dengan semua keterampilan baru yang dibutuhkan untuk meraih peluang dan menghadapi tantangan abad ke-21. Untuk bersaing dengan negara maju di dunia, sistem pendidikan harus mampu menghasilkan generasi muda yang berilmu, mampu berfikir kritis dan kreatif, memiliki jiwa kepemimpinan yang kuat, dan mampu berkomunikasi secara efektif dalam skala global. Tidak kurang pentingnya, setiap siswa di negara ini perlu menerapkan nilai-nilai kewarganegaraan, etika, dan tanggungjawab, agar mereka dapat membuat pilihan yang tepat untuk diri mereka, keluarga dan negara, serta berupaya mengharungi dan mengatasi segala rintangan (Kementerian Pendidikan Malaysia, 2013). Ini selaras dengan matlamat Belia Negara yang menekankan kepentingan melahirkan belia yang berilmu dan berkelayakan untuk pembangunan negara. Menurut laporan Jabatan Perangkaan Malaysia (2016), 39.6\% rakyat Malaysia yang tinggal di kawasan bandar hanya berpendidikan peringkat sijil SPM, 11\% berkelulusan diploma dan 37\% berkelulusan lanjutan. Ini adalah sasaran RMK-11 Malaysia untuk memastikan 1\% daripada belia miskin bandar mempunyai sekurang-kurangnya ijazah sarjana muda dalam pendidikan.

Ini berlaku adalah disebabkan oleh fenomena keciciran dalam pelajaran dan sekolah. Situasi ini adalah satu pembaziran dalam kemajuan pendidikan Malaysia. Fenomena ini dapat dilihat dalam masyarakat India di Malaysia, dimana pendidikan mereka rendah dan jauh di belakang daripada kaum yang lain. Laporan statistik Kementerian Pendidikan Malaysia (KPM) (2019) menunjukkan terdapat perbezaan yang ketara dalam tahap pendidikan kaum India berbanding kaum lain di Malaysia dimana 9\% daripada belia India berumur 20-24 mempunyai pendidikan rendah, berbanding dengan 6\% dalam masyarakat Melayu dan 5\% dalam masyarakat Cina. Menurut penyelidikan dan statistik pada tahun 2019 oleh Pertubuhan Sains dan Kesihatan (SWO) (2019), 4 daripada 10 pelajar India tercicir kerana pelbagai faktor.

Justeru secara ringkasnya, kertas konsep ini mengupas berkaitan faktor-faktor yang mempengaruhi keciciran pelajar dalam pembelajaran pada masa kini. Selain itu, kertas konsep ini juga mengupas berkaitan langkah-langkah dalam mengatasi isu keciciran dalam pembelajaran bagi pelajar-pelajar di Malaysia.

\section{Faktor Yang Mempengaruhi Keciciran dalam Pembelajaran}

\subsection{Faktor sosioekonomi keluarga}

Faktor utama berlakunya keciciran adalah sosioekonomi keluarga. Pengaruh latar belakang sosioekonomi keluarga terdiri daripada pendapatan keluarga, pekerjaan ibu bapa, tahap pendidikan ibu bapa, dan sokongan keluarga.

Pendapatan keluarga yang rendah memberikan kesan terhadap perkembangan pembangunan pendidikan di negara ini. Hal ini mengakibatkan rendahnya tingkat motivasi anak untuk terus belajar (Nor Azrul \& Noordeyana, 2018). Hal ini dibuktikan dengan sebuah kajian yang dilakukan oleh Kitha (2021), di bawah Program Perumahan 
Rakyat (PPR) di Kuala Putrajaya, di mana hingga 86\% dari populasi daerah tersebut termasuk dalam kelompok B40, dengan pendapatan rata-rata RM3000 dan kurang. Hasil kajian juga menunjukkan bahawa $80 \%$ anak yang tinggal di daerah ini hanya memiliki SPM sebagai tingkat pendidikan tertinggi dek kerana kekurangan pendapatan orang tua menyebabkan mereka hidup dalam kemiskinan dan mengabaikan pendidikan anakanaknya. Hal ini menyebabkan ibu bapa harus mempertimbangkan kewangan untuk keperluan dasar yang lebih penting untuk melanjutkan kelangsungan hidup. Sesetengah ibu bapa tidak dapat memenuhi keperluan dasar seperti menghantar anak ke sekolah dan tidak peduli dengan keperluan belajar anak (Ganesan, 2013). Menurut data yang dikeluarkan oleh Institut Hal Ehwal Ekonomi dan Demokrasi Malaysia (IDEAS) (2017), hampir $60 \%$ pelajar yang tercicir adalah daripada keluarga berpendapatan rendah, dan sebenarnya, ketidakhadiran ini memberi kesan kepada prestasi akademik pelajar.

Disamping itu, pekerjaan ibu bapa juga turut memainkan peranan dalam sosioekonomi keluarga. Kitha (2021) mendedahkan bahawa ramai orang di kawasan luar bandar menumpukan kepada aktiviti ekonomi utama, iaitu dengan menggunakan kaedah tradisional. Sebagai contoh, ibu bapa yang bekerja sebagai petani masih menggunakan kudrat diri untuk bercucuk tanam. Hasil tanaman yang dihasilkan adalah kurang dan pendapatan yang diperolehi adalah sedikit. Ini secara tidak langsung menjejaskan perbelanjaan ibu bapa termasuklah pendidikan anak-anak mereka. Kebanyakan mereka tidak mampu untuk menghantar anak-anak mereka ke pendidikan kerana tidak mempunyai pendapatan. Disebabkan pendapatan ibu bapa yang tidak mencukupi dan kesempitan kewangan keluarga, anak-anak mula melakukan kerja-kerja sambilan seperti mencuci kereta, penjual pasar malam dan kerja sambilan di taman perumahan berhampiran untuk menambah sara hidup mereka sekeluarga. Kanak-kanak ditipu dengan pendapatan yang lumayan dan tidak dapat meneruskan ke sekolah.

Selain itu, tahap pendidikan ibu bapa juga berhubung kait dengan keciciran pelajaran anak-anak. Menurut Sateesh dan T.V. Sekher (2014) latar belakang pendidikan ibu bapa mempengaruhi tingkat kemampuan anak-anak untuk menguasai pembelajaran. Pendapatan rumah tangga siswa yang rendah dan orang tua yang tidak berpendidikan mungkin tidak dapat membimbing anak-anaknya untuk mendapatkan pendidikan yang sempurna. Masalah pendidikan dan kewangan dapat menjadi hambatan untuk memberikan kesempatan pendidikan terbaik bagi anak-anak. Menurut Khalid et al. (2018), majoriti ibu bapa yang tergolong masyarakat miskin bandar memiliki latar belakang pendidikan yang lebih rendah sehingga membuat anak-anaknya kurang termotivasi untuk melanjutkan pendidikan ke jenjang yang lebih tinggi.

Jelaslah, bahawa status sosioekonomi keluarga yang rendah menjadi faktor penghalang kepada individu untuk memperolehi peluang pendidikan tinggi, dan sumber kewangan yang terhad menghalang kesediaan pelajar untuk menyambung pelajaran. Oleh karena itu, keluarga dengan status sosial ekonomi rendah tidak mampu memberikan pendidikan yang baik atau menyediakan fasiliti pendidikan yang sempurna untuk mendorong anaknya belajar dengan baik. Keterbatasan sumber daya kewangan tidak memungkinkan pelajar untuk melanjutkan pendidikan ke tingkat yang lebih tinggi.

\subsection{Faktor personaliti pelajar}

Faktor diri sendiri merupakan faktor yang paling mempengaruhi seseorang untuk mendapatkan pendidikan yang sempurna. Sikap, minat dan motivasi pelajar memainkan peranan penting dalam mempengaruhi keciciran di sekolah. 
Sikap, minat, dan aspek motivasi siswa sangat erat kaitannya dengan prestasi belajar seseorang. Menurut Jerie dan Zamri (2011), sikap adalah bersifat abstrak dan hanya dapat dilihat dan dirasakan melalui tindakan yang dilakukan. Sikap sangat mempengaruhi kecepatan pelajar belajar dan menguasainya dalam pendidikan. Sekiranya murid mempunyai sikap yang positif seperti menyedari kepentingan pembelajaran, maka murid akan cuba menguasainya dengan pelbagai cara. Kecemerlangan pelajaran adalah ditentukan pelajar itu sendiri. Akan tetapi jika sikap pelajar itu adalah sebaliknya seperti tidak mahu majukan diri dan tidak endahkan tentang kepentingan pendidikan, ia akan mengganggu proses pembelajaran dan terusnya akan mengakibatkan berlakunya keciciran dalam pelajaran.

Sebagai contoh, Orang Asli dikatakan mempunyai personaliti yang unik berbanding dengan kanak-kanak yang mempunyai usia sama yang menetap di bandar. Dalam kajian oleh Nik Nur Azizah et al. (2018), menyatakan bahawa murid Orang Asli pemalu, agak sensitif, sukar menerima kedatangan orang luar dan bersikap pasif di dalam kelas. Menurut Alia dan Norwaliza (2021), sifat pemalu murid-murid melambatkan proses pengajaran dan pembelajaran kerana interaksi dan komunikasi yang lemah dan sifat yang sensitif itu menyukarkan murid Orang Asli memajukan diri sendiri dari pendidikan. Lantaran itu, proses pembelajaran menjadi perlahan dimana guru tidak dapat mengenal pasti tahap pemahaman terhadap pelajaran yang disampaikan.

Selain itu, minat pelajar yang berkurang akan pelajaran turut menjadi faktor kepada keciciran dalam pelajaran. Menurut Hamzah Uno (2011) minat merupakan sumber motivasi bagi seseorang yang mendorongnya untuk melakukan sesuatu yang diinginkannya. Dengan minat, seseorang akan dengan senang hati melakukan sesuatu, termasuklah minat untuk belajar. Minat belajar juga dapat ditafsirkan sebagai kegembiraan, semangat, atau kesenangan dalam sesuatu. Minat terhadap pembelajaran adalah salah satu faktor dalaman aspek psikologi yang sangat berpengaruh dan memainkan peranan penting dalam aktiviti proses pembelajaran dan perkembangan pembelajaran dan kejayaan pelajar (Zaenol et al., 2021). Minat terhadap pembelajaran adalah aspek psikologi yang mendorong proses pembelajaran yang mana ianya tidak timbul dengan sendirinya, tetapi dipengaruhi oleh pelbagai faktor yang menyebabkan timbulnya minat untuk belajar dalam diri. Minat yang tinggi pada seseorang pelajar akan memudahkan proses pembelajaran.

Menurut Rusmiati (2017), minat mempunyai pengaruh yang besar terhadap pembelajaran, kerana jika bahan pembelajaran tidak sesuai dengan minat pelajar, mereka tidak akan belajar dengan baik kerana tidak ada daya penarik. Keadaan ini akan menyebabkan pelajar-pelajar tidak fokus pada pelajaran dan suka berangan-angan di dalam kelas. Pelajar akan hilang tumpuan akan pelajaran dan lama-kelamaan akan timbul rasa untuk ponteng sekolah dan ini menyumbang kepada keciciran dalam pendidikan. Sebaliknya, pelajar yang berminat dengan topik tertentu akan memberi lebih perhatian kepada topik tersebut dan terlibat secara kognitif di dalamnya. Pelajar yang berminat dengan apa yang mereka pelajari akan menunjukkan pencapaian akademik yang lebih tinggi dan lebih cenderung untuk mengingati isi pelajaran berbanding dengan pelajar yang kurang berminat.

Seterusnya adalah motivasi diri pelajar. Motivasi ini akan mendorong dan membantu seseorang untuk melakukan sesuatu, baik dalam keadaan sedar mahupun tidak sedar. Motivasi ini mungkin terkait dengan minat seseorang untuk melakukan atau tidak 
melakukan sesuatu secara terus menerus (Nuradibah \& Hazlina, 2016). Motivasi sangat penting dalam proses pembelajaran karena dapat menentukan arah dan keberkesanannya. Jika pelajar tidak memiliki motivasi diri untuk menerima pelajaran, pelajar cenderung berkompromi dan mengikuti pendapat dan nasihat orang lain tanpa ada pertimbangan yang wajar. Kekurangan motivasi dalam diri pelajar akan menyebabkan pelajar terlibat secara langsung dalam gejala-gejala sosial yang pada akhirnya akan membawa kepada keciciran dari sekolah. Keadaan ini telah memaksa pelajar terlibat dalam aktiviti gejala sosial seperti ponteng sekolah dan terlibat dalam gengster atau kongsi gelap untuk mendapatkan sumber kewangan. Menurut Ghandi dan R. Sivaperagasam (2019) bahawa 3:10 daripada pelajar India terlibat secara aktif dalam kegiatan gengsterisme daripada data yang diperoleh dari Polis Diraja Malaysia. Ini telah menjadi masalah sosial utama dalam kalangan pelajar India dan seterusnya menghilangkan minat pelajar untuk melanjutkan pelajaran.

Ini terbukti dalam laporan oleh Simon (2011) dalam BBC News bertarikh 24 Ogos 2011, dimana penelitian kajian menyatakan bahwa kegagalan pendidikan disebabkan oleh masalah seperti kurangnya kontrol diri, kepercayaan diri, hilangnya motivasi diri, status kesihatan yang rendah kerana terlibat dalam masalah gejala sosial. Antaranya ialah terlibat dengan merokok, mengambil dadah, tekanan jiwa, dan masalah mental. Pelajar yang tercicir pelajaran lebih cenderung untuk terlibat dengan masalah sosial malahan jenayah juga.

\subsection{Faktor luaran}

Keciciran juga boleh berlaku akibat faktor luaran seperti budaya dan persekitaran, gaya pengajaran guru serta pengaruh rakan sebaya.

Budaya dan persekitaran juga merupakan faktor yang mempengaruhi prestasi pelajar. Contohnya dalam kajian Nik Nur Azizah et al. (2018), orang Asli masih berpegang dengan tradisi nenek moyang mereka walaupun pelbagai bantuan dan insentif daripada kerajaan dalam memartabatkan pendidikan masyarakat orang Asli. Kini, kehidupan orang Asli masih berhubung rapat dengan alam semula jadi. Alam semula jadi dan hutan sebagai sumber utama masyarakat orang Asli mencari rezeki. Akibatnya, mereka masih berpuas hati dengan keadaan lama mereka dan sukar menerima perubahan dalam kehidupan mereka terutama dalam bidang pendidikan. Persekitaran nenek moyang mereka secara tidak langsung mempengaruhi hala tuju kemajuan masyarakat orang Asli. Pengaruh budaya dan persekitaran yang kuat dalam diri pelajar menyebabkan pelajar tidak berminat untuk mendapatkan pendidikan dan seterusnya berlakunya peningkatan dalam keciciran.

Seterusnya, pengaruh rakan sebaya merupakan penyumbang kepada faktor keciciran dalam pelajaran. Teman sekelas yang duduk bersebelahan berperan penting dalam merangsang fikiran pelajar untuk terus tetap fokus pada pengajaran guru. Kajian Alia dan Norwaliza (2021), menunjukkan bahawa pelajar yang gemar tidur di dalam kelas akan mempengaruhi rakan-rakannya untuk tidur di dalam kelas juga. Dalam diri pelajar, sifat ingin meneroka dan meniru perangai rakan sebaya adalah perkara biasa dalam pembangunan holistik dimana pelajar ingin cuba dan ingin membuat lebih daripada rakan mereka lakukan. Rakan sebaya yang suka membuat kerja sekolah bersama-sama memberi nilai tambah yang baik kepada rakan sebaya mereka, tetapi rakan sebaya yang suka membuat sesuatu keburukan bersama-sama rakan sebaya akan memudaratkan diri mereka. 
Gaya pengajaran guru yang membosankan turut menjadi faktor berlakunya keciciran. Gaya pengajaran yang tradisional membuatkan pelajar kurang berminat dan cepat bosan. Sebahagian besar pelajar akan tertarik untuk belajar jika guru memainkan peranan penting di dalam kelas. Guru yang bijaksana adalah guru yang mampu untuk meningkatkan minat pelajar dengan memberikan kaedah yang tepat untuk melakukan kegiatan pembelajaran di kelas. Sikap negatif pelajar terhadap sekolah dan guru dapat mengurangi minat dan motivasi mereka dalam mempelajari mata pelajaran yang diajarkan oleh guru. Cara guru yang kreatif dan sentiasa mengikuti media masa perlu disemaikan dalam diri pengajar dalam menarik minat pelajar untuk mempelajari ilmu di sekolah. Media masa seperti tiktok, dan facebook adalah media yang sesuai dalam memberikan ilmu pada pelajar. Anjakkan paradigma pendidikan dalam melopori ilmu teknologi maklumat boleh memperbanyak gaya pengajaran bagi menarik minat pelajar untuk meneroka ilmu. Guru yang mengamalkan cara tradisional dalam pengajaran dan pembelajaran akan menyebabkan pelajar hilang tumpuan dan akhirnya akan membawa kepada berlakunya keciciran.

\section{Langkah- langkah dalam mengatasi isu keciciran}

\subsection{Tingkatkan kesedaran ibubapa}

Dalam mengatasi masalah keciciran yang disebabkan oleh sosioekonomi keluarga, pihak kerajaan dan sekolah perlu memainkan peranan utama. Kerajaan dan sekolah perlu memberikan pendedahan kepada ibu bapa tentang keperluan pendidikan untuk anakanak. Ibu bapa seharusnya memberi dorongan dan galakan kepada anak-anak mereka untuk sentiasa menghadiri sekolah. Dengan mendapatkan pendidikan formal, anak-anak boleh berjaya dalam pelajaran dan membantu mengubah nasib keluarga mereka pada masa hadapan. Selain itu, ibu bapa hendaklah terlibat secara aktif dalam setiap aktiviti yang dianjurkan oleh pihak sekolah . Misalnya pada hari orientasi persekolahan dimana ibu bapa dan pihak sekolah boleh membincangkan prestasi pendidikan anak mereka di sekolah.

Misalnya, Jabatan Pendidikan Negeri Selangor (JPNS), Pejabat Pendidikan Daerah (PPD) Negeri Selangor dan sekolah mengambil inisiatif menghubungi ibu bapa atau penjaga bagi mengesahkan keadaan persekolahan anak, menyediakan perkhidmatan kaunseling seperti kelas pemulihan, dan menganjurkan aktiviti ziarah sekolah dari semasa ke semasa bagi mengurangkan masalah keciciran sekolah. Selain itu, inisiatif untuk meningkatkan penyertaan pelajar dari pra-rendah ke sekolah menengah juga telah dibangunkan dengan tujuan meningkatkan enrolmen pelajar di sekolah di semua peringkat dan menangani isu keciciran. Inisiatif ini seiring dengan Pelan Pembangunan Pendidikan Malaysia 2013-2025 (Kementerian Pendidikan Malaysia, 2013) yang mana ingin mengurangkan isu keciciran dalam kalangan pelajar.

Di samping itu juga, Kementerian Pendidikan Malaysia (KPM) 2019, melalui pihak sekolah telah menyediakan pelbagai bantuan seperti buku teks percuma, rancangan makanan tambahan (RMT), program susu pelajar, dan menyediakan perkhidmatan kaunselor dan guru pemulihan bagi meningkatkan minat pelajar untuk menyambung pelajaran. Bantuan yang disalurkan oleh kementerian ini sedikit sebanyak dapat meringankan beban ibu bapa berkaitan dengan kos pelajaran anak-anak. Oleh itu, 
sekolah berperanan untuk menyalurkan bantuan daripada kementerian kepada pelajarpelajar yang tergolong dalam golongan B40.

\subsection{Tingkatkan motivasi dan minat pelajar}

Dalam mengatasi masalah keciciran pendidikan akibat daripada faktor pelajar itu sendiri, peranan ibu bapa, guru dan sekolah amat penting. Ibu bapa berperanan untuk memupuk personaliti anak-anak daripada sejak kecil lagi. Menurut kajian White dan Kelly (2010), ibu bapa haruslah menunjukkan contoh teladan yang baik kepada anakanak. Ini kerana anak-anak mendapatkan pendidikan awal bermula daripada rumah. Oleh itu, ibu bapa perlu menerapkan dalam diri anak-anak akan kepentingan dan minat untuk mendapatkan pendidikan sempurna supaya tidak tercicir.

Selain itu, sekolah juga turut berperanan untuk mengadakan kempen-kempen motivasi yang mana akan memberi kesedaran kepada pelajar tentang pentingnya pendidikan. Menurut Nuradibah dan Hazlina (2016), pelajar yang termotivasi biasanya memiliki dorongan yang kuat untuk tetap tertarik dengan apa yang disampaikan termasuklah untuk mendapatkan pendidikan yang sempurna. Ini berlaku daripada rangsanganrangsangan dan dorongan motivasi daripada masyarakat sekeliling pelajar. Insentif dalam pengajaran dan pembelajaran sering disampaikan seperti markah, gred, wang, pujian, penghargaan, tanda bintang dan sebagainya akan menarik minat pelajar untuk belajar dengan bersunguh-sungguh. Motivasi juga muncul dari dorongan atau kecenderungan individu untuk menggerakkan individu bertindak untuk mencapai sesuatu, bahkan untuk jangka waktu yang lama. Oleh itu, pelajar yang memiliki kecenderungan dan minat yang berbeza perlu dibantu supaya mereka akan tertarik untuk belajar. Kementerian Pelajaran Malaysia (KPM) (2019) juga telah melaksanakan kolaborasi dengan pelbagai pihak untuk melancarkan program-program pendidikan demi mengurangkan masalah keciciran Antaranya ialah, Program Perantisan Industri Menengah (PIMA) dimana ini adalah program aliran kemahiran di sekolah menengah yang dilaksanakan secara kolaboratif antara kementerian pendidikan dan institusi industri atau latihan. Inisiatif pelaksanaan program ini adalah satu usaha untuk membantu mengurangkan risiko keciciran dalam kalangan pelajar sekolah menengah yang tidak berminat dalam bidang akademik dan alternatif untuk melanjutkan pelajaran melalui latihan industri serta akademik. Program ini dijalankan adalah untuk membantu pelajar yang tidak minat dengan pelajaran untuk menceburi bidang kemahiran supaya masa depan pelajar terjamin.

\subsection{Pelbagaikan cara pengajaran guru}

Terdapat cara yang berbeza untuk guru melibatkan pelajar semasa proses pengajaran dan pembelajaran di dalam bilik darjah, dan salah satunya adalah dengan menggunakan kaedah pengajaran yang menyeronokkan. Penggunaan bahan bantu mengajar seperti carta, gambar, dan graf dapat menjelaskan konsep yang diperkenalkan oleh guru (Mohammad Aziz \& Shah Mohamed, 2014). Guru perlu menggunakan banyak pendekatan dan kaedah untuk menarik minat pelajar dalam menguasai pelajaran yang diajar. Guru yang berfikiran positif boleh menyediakan peluang pembelajaran dengan mempertimbangkan gaya pembelajaran.

Misalnya dalam kajian Nik Nur Azizah et al. (2018) menyatakan bahawa bagi masyarakat orang Asli, mendapatkan pendidikan formal adalah bukan budaya mereka, sehingga mereka tidak mementingkan bidang pendidikan. Oleh kerana itu, guru perlu 
menggunakan inisiatif kreatif dalam pendidikan dan pembelajaran (P\&P) untuk menarik masyarakat orang Asli untuk belajar menggunakan pendekatan yang berbeza dimana menggunakan pendedahan kepada alam semula jadi. Ini adalah inisiatif terbaik yang boleh diterapkan. Pendekatan ini boleh bermula dengan persekitaran pengajaran dan pembelajaran (P\&P) yang berlaku di dalam bilik darjah, dan digantikan dengan persekitaran pembelajaran di luar bilik darjah. Apabila orang asli dekat dengan alam semula jadi, ia mewujudkan persekitaran pembelajaran yang membolehkan mereka untuk belajar. Ini kerana orang Asli dan alam semula jadi tidak dapat dipisahkan.

Selain itu, guru boleh mengajar dan belajar (P\&P) secara dalam talian. Mengikut Pelan Pembangunan Pendidikan Malaysia 2013-2025, pembelajaran dan pengajaran dalam talian merujuk kepada Buku Panduan Pengajaran dan Pembelajaran di Rumah, Versi 2, yang dikeluarkan oleh Kementerian Pendidikan Malaysia (KPM) (2019), yang ditakrifkan sebagai pengajaran di rumah (PdPR), di mana rumah atau pusat komuniti atau Pengajaran dan Pembelajaran (PdP) dilaksanakan di mana-mana lokasi yang sesuai. PdPR boleh dilaksanakan secara online atau offline secara tersusun dan terancang. PdPR dilaksanakan apabila pelajar tidak dapat hadir ke sekolah dalam tempoh masa tertentu akibat bencana atau wabak atau sebab lain. Ini akan memudahkan pelajar mengakses kursus tidak kira di mana mereka berada. Oleh itu, masalah keciciran dapat dikurangkan

\section{Kesimpulan}

Sistem pendidikan negara kita mengalami perubahan kepada pendekatan yang lebih bertepatan dengan keperluan setempat. Perubahan ini memberi kesan langsung terhadap perkembangan pendidikan yang selaras dengan era globalisasi yang melibatkan semua peringkat sekolah seperti sekolah rendah, menengah dan juga institusi tinggi. Apa yang pasti, jurang pendidikan yang diwujudkan oleh keciciran dalam pendidikan masih wujud dan akan mengecil apabila keperluan asas berterusan, dan Kementerian Pendidikan perlu meneliti secara terperinci akan sistem pendidikan sekarang supaya usaha melonjakkan sektor pendidikan ke peringkat lebih tinggi dapat dilaksanakan. Kemajuan sesebuah negara amat bergantung kepada generasi muda yang seimbang dari segi intelek, fizikal, mental dan emosi dalam pelbagai segi, terutamanya segi teknologi dan ekonomi. Oleh itu, halangan untuk menjana modal insan yang berdaya maju perlu dikenal pasti bagi melaksanakan pendekatan yang betul.

Dalam memperkasakan sektor pendidikan, Kementerian Pendidikan Malaysia (KPM) memberi bantuan pendidikan sekolah untuk memastikan semua sekolah dan pelajar mempunyai peluang dan kebolehan yang sama untuk cemerlang dalam kurikulum dan aktiviti kokurikulum dalam Pelan Pembangunan Pendidikan Malaysia 2013-2025 (Kementerian Pendidikan Malaysia, 2013). Kejayaan dalam merapatkan jurang pendidikan boleh dicapai melalui usaha berterusan dan komitmen daripada semua pihak terutamanya eksekutif sektor pendidikan, ibu bapa, NGO, kumpulan masyarakat dan pelabur. Justeru, semua pelaksana perlu memberikan perhatian dan pelaburan yang tinggi bukan sahaja dalam proses pengajaran dan pembelajaran (P\&P) pelajar, tetapi juga terhadap kebajikan dan keperluan sosial pelajar khususnya di luar bandar

Untuk kajian yang akan datang dicadangkan untuk mengkaji kesan dan implikasi akibat daripada keciciran dalam pembelajaran terhadap masyarakat dan negara. Ini adalah kerana untuk membentuk sebuah negara maju, pembangunan modal insan yang akan menjadi guna tenaga kepada negara merupakan elemen yang sangat penting. Kajian 
berkaitan kesan keciciran dalam pendidikan memberi signal tentang pertumbuhan ekonomi sesebuah negara. Selain itu, kajian berkaitan keciciran dalam pendidikan mengikut jantina, lelaki dan perempuan, juga boleh dijalankan. Ini adalah untuk mengkaji golongan yang banyak tercicir dalam pelajaran.

\section{Penghargaan (Acknowledgement)}

Terima kasih kepada pensyarah yang telah banyak memberi tunjuk ajar dalam menghasilkan kajian ini. Selain itu, terima kasih juga kepada ibu bapa dan keluarga yang banyak memberi dorongan dan sokongan serta rakan-rakan dalam menjayakan kajian ini.

\section{Kewangan (Funding)}

Kajian dan penerbitan ini tidak menerima sebarang tajaan atau bantuan kewangan daripada mana-mana pihak.

\section{Konflik Kepentingan (Conflict of Interests)}

Tidak ada mempunyai konflik kepentingan dalam kajian ini.

\section{Rujukan}

Alia Nordina Nordin \& Norwaliza Abdul Wahab. (2021). Kertas Konsep Pembangunan Modul Sekolah Rimba Berasaskan Pengetahuan Peribumi Bagi Mengekalkan Kelestarian Masyarakat Orang Asli. Asian Pendidikan, 1(1), 10-21.

Ganesan Kamoo. (2013), Pengaruh keluarga terhadap pencapaian akademik murid India di sekolah Menegah Rendah. Ph.D thesis, University of Malaya. https://studentsrepo.um.edu.my

Ghandi M. S. D., \& R. Sivaperagasam, P. R. (2019). Implikasi status sosioekonomi keluarga dan persekitaran terhadap keciciran murid India : Kajian kes di Puchong. International Journal of Education, Psychology and Counseling, 4(33), 284-297.

Hamzah Uno. (2011). Teori Motivasi Dan Pengukurannya: Analisis Di Bidang Pendidikan (Cet. 14). Jakarta: Bumi Aksara.

Institut Hal Ehwal Ekonomi dan Demokrasi Malaysia (IDEAS). (2017). Laporan keciciran pelajar. Kuala Lumpur. Percetakan Nasional Berhad (PNB).

Jabatan Perangkaan Malaysia. (2016). Laporan penyiasatan pendapatan isi rumah dan kemudahan asas mengikut negeri dan daerah pentadbiran. Putrajaya: Jabatan Perangkaan Malaysia.

Jerie, P. L., \& Zamri Mahamod. (2011). Sikap dan motivasi murid Iban dalam mempelajari bahasa Melayu sebagai bahasa kedua. Jurnal Pendidikan Bahasa Melayu, 1(1), 13-25.

Kementerian Pendidikan Malaysia. (2013). Pelan Pembangunan Pendidikan Malaysia. Kuala Lumpur. Percetakan Nasional Berhad (PNB).

Kementerian Pendidikan Malaysia. (2019). Perangkaan Tahunan Pendidikan Pelbagai Tahun. Kuala Lumpur. Percetakan Nasional Berhad (PNB).

Khalid, M. A., Siti Nur Fatimahtul Maryam, A., Zouhair, R., \& Endie Shazlie, A. (2018). Children Without: A study or urban child poverty and deprivation in low-cost flats in Kuala Lumpur. Malaysia: United Nations Childrens' Fund. 
Kitha Anjali. (2021). Keciciran dalam pendidikan di Malaysia. https://www.academia.edu/23788053/Keciciran_Dalam_Pendidikan_Malaysia

Mohammad Aziz \& Shah Mohamed Arip. (2014). Faktor, kesan dan strategi menangani permasalahan kurang tumpuan pelajar sekolah menengah di dalam kelas : Satu Kajian Kualitatif. In : International Counseling Conference and Work, 13-15 Sept 2014, Medan.

Nik Nur Azizah Nik Halman, Ramle Abdullah \& Norizan Mamat, (2018). Keciciran Pendidikan di peringkat sekolah rendah dalam kalangan murid Orang Asli Hulu Terengganu. Prosiding Seminar Kebangsaan Majlis Dekan Pendidikan Universiti Awam.

Nor Azrul Mohd Zin \& Noordeyana Tambi. (2018). Faktor Kemiskinan Bandar terhadap Pembangunan Pendidikan Golongan Lewat Kembang. Jurnal Psikologi Malaysia, 32(3), 119-130.

Norkhatijah Murni Othman @ Ismail, Poo Bee Tin, \& Zaimah Darawi. (2012). Analisis Perubahan Komposisi Guna Tenaga dalam Industri Perkhidmatan di Malaysia. Prosiding PERKEM VII. Jilid 2 (2012), 959 - 966.

Nuradibah Asbullah \& Hazlina Abdul Halim (2016). Motivasi Pelajar Mobiliti Dalam Pembelajaran Bahasa Perancis. Jurnal Kesidang, 1(1), 86 - 101.

Perlembagaan Malaysia 2013 (Malaysia)

Pertubuhan Sains dan Kesihatan (SWO). (2019). The Malaysian Indian Community.

Rusmiati. (2017). Pengaruh Minat Belajar Terhadap Prestasi Belajar Bidang Studi Ekonomi Siswa Ma Al Fattah Sumbermulyo. Jurnal Ilmiah Pendidikan dan Ekonomi, 1(1), 21-36.

Sateesh Gouda M. \& T. V. Sekher. (2014). Factors leading to school dropouts in India: An analysis of national family health survey-3 data. International Journal of Research \& Method in Education, 4(6), 75-83.

Simon, C. (2011, August 24). BBC News. United Kingdom.

Subra, TH., Abdullah, M. A. I. L., \& Devi, K. (2019). Ketahanan Diri dalam Mempengaruhi Aspek Keciciran Pelajar India di Daerah Kuala Muda, Kedah: Satu Kajian Kes. International Journal of Modern Education, 1(3), 10-23.

White, S., \& Kelly, D. (2010). The school counselor's role in school dropout prevention. Journal of Counseling and Development, 88(2), 227-235.

Zaenol Fajri, Hasan Bahrun, Chusnul Muali, Shofiatun, Lilik Farida \& Yulis Wahyuningtiyas. (2021). Student's Learning Motivation and Interest; The Effectiveness of Online Learning during COVID-19 Pandemic. Journal of Physics: conference series. 